\title{
Psychological Well-Being in Student of Gender Difference
}

\author{
Miss. Sana Akhter ${ }^{1}$
}

\section{ABSTRACT}

The aim of the present study was investigated to psychology well -being of gender Difference. The random sampling Method was used in this study. The total sample consisted 100 students. 50 of male and 50 of female of 10th standard students selected from the Jamshedpur city. Ryff'sscales of psychological well-being scale developed by Carol Ryff (1989) was used to measure the psychological well-being. In this research psychological well-being Inventory was used for data collection Data was analyzed by' $t$ ' test verify the hypothesis. The result shows that ' $t$ ' value is 5.68 that is significant at 0.01 level. So, the hypothesis is accepted. . Results showed significant gender differences in the levels on psychological well-being. It means male and female students are difference in psychological well-being.

Keywords: Psychological well-being, Student, Gender Difference.

Few people doubt that happiness is very important. Starting at least with the Ancient Greeks, the concept continues to be subject of unremitting debate. Surely such debate would not start if people generally felt the issue did not matter. Since happiness captures and continues to capture the interest of so many people, philosophers and many others debating the concept have long yearned for a way to measure happiness. PWB is not the same as happiness although the terms are in-use synonymously. PWB is a broad category of phenomena that includes people's emotional responses, domain satisfactions, and global judgments of life satisfaction.

Psychological well- being has been defined as "engagement with existential challenges of life (Keyes, Shmotkin, \&Ryff 2002, p. 1007) and in this vein is arguably best represented by Ryff's (1989) conception of the six factors of PWB. To clarify psychological well-being and its measurement, Ryff (1989) developed a theoretically derived multidimensional scale, which intergraded a number of different perspectives within one measurement model. The Ryff measure taps 6 core dimension of psychological well-being that are common to the mentalhealth, clinical, and life-course developmental theories of positive psychological functioning.

${ }^{1}$ Research Scholar, Kolhan University, Chaibasa, Jharkhand

(C) 2015 I S Akhter; licensee IJIP. This is an Open Access Research distributed under the terms of the Creative Commons Attribution License (http://creativecommons.org/licenses/by/2.0), which permits unrestricted use, distribution, and reproduction in any Medium, provided the original work is properly cited. 


\section{Psychological Well-Being in Student of Gender Difference}

These 6 dimensions are: self-acceptance, or positive attitudes toward oneself; positive relation with others, including the ability to achieve close union with others; autonomy, including qualities of self-determination, independence, and the regulation of behavior from within; environmental mastery, with is the individual's ability to engage in, and manage, activities in one's surrounding world; purpose in life, including the beliefs that give one the feeling that there is purpose in and meaning of life; and personal growth, which represents one's continual development and striving to realize one's potential to grow and expand as a person.

Having a positive psychological well-being (PWB) is crucial for successfully navigating a new environment, engaging in meaningful relationships, and realizing one's fullest potential throughout one's lifespan (Allport, 1961; Erickson, 1959; Maslow, 1968; 5 Rogers, 1961; Ryff, 1989). Ryff's(1989a,1989b) multidimensional psychological wellbeing model examines six constructs identified and defined as follows:

- Self-acceptance reflects a positive evaluation of self and past life experiences (Ryff\& Keyes, 1995).

- Positive relations with others emphasize the importance of trusting, satisfying interpersonal relationships with others (Rogers, 1961).

- Autonomy refers to an individual having an internal locus of evaluation and not looking to others for approval, but using personal standards for evaluating self (Rogers, 1961).

- Environmental mastery is the capacity to choose and manage effectively environments suitable to their strengths (Ryff, 1989).

- Purpose in life is predicated on the belief that life has meaning and purpose.

- Personal growth is having continued development, as characterized by self-actualization (Maslow, 1968; Ryff\& Keyes, 1995; Van Dierendonck, 2003).

\section{PSYCHOLOGICAL WELL-BEING AMONG GENDER}

Gender differences do exist because of biological and psychological differences. The level of satisfaction with life among males and females can differ. When these differences interact with organizational environment or situations they can lead to different outcomes. The differences could be because of comfortable and better personal/family life, good interpersonal relationships (both in workplace and outside), effective communications skills and also certain other factors like more leniency towards female employees, better facilities, lower expectations and ambitions than the male employees.

Gender differences in Psychological well-being are important because of the many efforts being made in contemporary society to empower all individuals to achieve self-actualisation and utilise their full potential. In a post-feminist context this incorporates the idea of an "equal opportunities" society; yet social stereotypes still remain (Connors, 1990; Eagly, 1987; Turner \&Sterk, 1994). All people are equal but not identical, and the possible differences between people need to be considered in order to empower all individuals to achieve self-actualisation 
and to fulfil their potential (thereby promoting optimal psychological well-being), whilst being offered equal opportunities. Current studies on the existence of gender differences, including those related to psychological well-being reflect contradictory result and a distinct lack of consensus (Ryff\& Singer, 1998, Strumpfer, 1995). Based on their own literature studies and qualitative experiences, Crose et al (1992) believe that gender differences do exist in almost every aspect of health and health care. In a Taiwanese study, Lu (2000) discovered gender differences while examining conjugal congruence on role experiences and subjective wellbeing.Inglehart (2002) finds that in almost every society, men have higher incomes, more prestigious jobs and more authority than women--all links with relatively high levels of subjective well-being. So women show low level of happiness than men. Research supports that men and women have similar levels of happiness and overall life satisfaction. Gender related differences on psychological well-being supports the notion that males tend to score higher on psychological well-being indicators in comparison to females. In a study by Carmel, it was found that women scored lower than men on psychological indicators of well-being (as cited in Carmel \&Nigavekar 2007).

\section{PSYCHOLOGICAL WELL-BEING IN STUDENTS}

Well -being is a concept that encompasses a well-rounded, balanced ,and comprehensive experience of life .It includes health in social , physical, mental, emotional ,career, and spiritual domains. Social support is a construct included in two studies about psychological well-being of university students. First, Aydin (1999) conducted a research of which one of the aims was to find out the relationship between how university students perceive the social support and their psychological well-being. Researcher concluded that social support, which is provided by family, did not have a significant effect on psychological well-being of university students in their first semester whereas social support provided by friends had a low but significant effect on psychological well-being. Then, Gençöz and Özlale (2004) also studied the effects of social support to psychological well-being of university students and concluded that "appreciationrelated social support had a direct effect on psychological well-being” (p. 449).Ryff proposed that the prior theories of positive functioning research served as the theoretical foundation for Ryff's multi-dimensional model of well-being. Over the last two decades, the Ryff Scales have been used in numerous empirical studies, that include research on work (Black, 1990), relocation (Ryff\& Essex, 1992), personality and wellbeing (Schmutte\&Ryff, 1997), and enhancing the ability of talented students to improve their potential (Jin \& Moon, 2006; Moon, 2003). In addition, the Ryff model has been used to examine college students' level of depression, value system, and perfectionism (Chang, 2006; Kitamura, Matsuoka, Miura, \&Yamaba, 2004; Sheldon, 2005).

Kitamura, Matsuoka, Miura, and Yamaba (2004), tested the theoretical model of psychological well-being with 574 Japanese university students. They found a factor 25 structure similar to Ryff's original model. Depression and anxiety correlated only moderately with scores on some 


\section{Psychological Well-Being in Student of Gender Difference}

subscales of the inventory, which suggested the relative independence of these dimensions of psychological well-being and negative affectivity.

When the researchers controlled for negative affectivity, earlier life experiences were significantly linked with psychological well-being (Kitamura et al, 2004). Sheldon (2005) examined whether 109 (18 men and 91 women) graduating seniors adopted healthier values as they matriculated through college. Intrinsic (community, intimacy, and growth) and extrinsic (money, popularity, and appearance) values were defined using Kasser and Ryan's (1993, 1996, 2001) distinction. The study revealed that graduating seniors shifted away from extrinsic to more intrinsic values when compared to their freshman year scores. Graduating seniors with the greatest intrinsic value shifts also reported greater increases in psychological well-being over their college career (Ryff\& Keyes, 1995).

Chang (2006) examined the relationship between perfectionism, stress, and psychological wellbeing mediated the relationship between perfectionism and autonomy, environmental mastery, and purpose in life; and greater stress was associated with lower psychological well-being. As stress increases, overall adjustment decreases, making students more susceptible to social and psychological problems and poor academic performance (Wintre\&Yaffe, 2000). The above studies showed that psychological well-being can directly influence students' levels of depression, value systems, and perfectionism. It was reported that students' psychological wellbeing was negatively related to these areas. For instance, as students experienced more stress, their level of psychological well-being decreased.

Ryff's model involves the individual's perception of engagement given the existential challenges of life (Keyes, Shmotkin, \&Ryff, 2002). The level of student engagement and involvement determine their cognitive and social development; with the greatest gains transpiring when students actively experience a supportive and mutually reinforcing higher education environment (Milem et al., 2005). Ryff's model of well-being was selected for this research because of its convergence and operatonalization of prior positive functioning theories from a theoretical to an empirical level (Fernandes, Vasconcelos-Raposo, \&Teixeira, 2010) and its relevance to the optimization of student potential (Moon, 2003) and because its role in academia has been studied. Barnes, Potter, and Fiedler's (1983) research indicated that stress has a predictive relationship to academic task performance, and high expectations and pressures of a new academic environment increase student anxiety (Cooke, Beewick, Barkham, Bradley, \&Audin, 2006; Price, McLeod, Gleich, \& Hand, 2006; Wong, Cheung, Chan, Ma, \& Tang, 2006). Environmental stress significantly inversely relates to academic performance and impairs the performance of less academically gifted students or students who struggle to adjust to the higher education environment (Barnes et al., 1983; McCann \&Meen, 1984). Higher education concerns about students' environmental mastery, self-acceptance, positive relations with others, and autonomy further establish the Ryff model as the appropriate model will be used in this study. 


\section{RELATED STUDY:}

ShamsulSiddiqui(2015) 'Gender Differences between Assertiveness and Psychological Well Being among University Students'. The findings of the study was show that, a significant difference was found between Psychological well-being of both Male and Female groups.

\section{METHODOLOGY}

\section{Objective-}

To compare psychological well-being of male and female students.

\section{Hypotheses-}

There will be a significant gender difference on psychological well-being among male and female students.

\section{Variable}

\section{Independent}

10th standard students at two levers

A1- male students.

A2 -female students.

Depended variable-

To get score on psychological well- being among male and female students.

\section{Sample-}

The sample consisted of 100 students. (50 of male and 50 of male of 10 th standard students) the sample was selected by random method from Jamshedpur, Jharkhand.

\section{Tools-}

In this research psychological well-being questionnaire where used from the data collection. it was constructed and standardized by Ryff `s scales of psychological well-being scale developed by Carol Ryff (1989). The scale consists of 54 items. Which consists a series of statement reflecting the six areas of psychological well-being: self-acceptance, positive relation with others, autonomy, environmental mastery, purpose in life and personal growth. Respondents rate statement on a scale of 1 to 6, with 1 indicating strong disagreement and 6 indicating strong agreement. The internal consistency coefficients of the scale between 0.86 and 0.93 .

\section{Research Design}

10th standard students at two levers

A1 - male students.

A2 - female students. 


\section{Psychological Well-Being in Student of Gender Difference}

\section{Statistical Method}

To verify the research objectives data was analyzed by t-test.

Table:

't' Score of Psychological Well-being among Male and Female Students

\begin{tabular}{lllccc} 
Variable & Sample-N & Mean & S.D & 't' value & Sig $-\mathrm{L}$ \\
\hline Male & 50 & 50.50 & 4.55 & & \\
Female & 50 & 55.90 & 5.00 & 5.68 & $\mathrm{P}<.01$ \\
\hline
\end{tabular}

\section{RESULT DISCUSSION-}

The main objective of present study was study of psychological well-being among male and female students .in it statistical ' $t$ ' method Wailed Results discussions of present study is as under. The result obtained on the psychology well -being reveals no significant difference of girls and boy students.

Table indicate that mean and standard deviation of male and female for psychological well-being is 50.5, 4.55 and 5.90, 5.00 respectively, which suggest that there is a difference among male and female on the score of psychological well-being, The ' $t$ ' value of psychological well-being was 5.68. Therefore, these differences are significant for psychological well-being among the male and female students. According to the ' $t$ ' test the numeric value that we get is 5.68 which is significant at 0.01 level. Therefore the hypotheses that there is significant difference between male and female in psychological well-being is acceptable, it means there is significant difference in psychological well-being among male and female students.

\section{CONCLUSION}

On the basis of the results of this study it can be concluded that there is a statistically significant difference in the psychological well-being among male and female students.

\section{REFERENCE}

Allport, G. W. (1961). Pattern and Growth in Personality.New York, NY: Holt, Rinehart, and Winston.

Aydın, D. (1999). Social network composition, social support and psychological well-being in first year METU students: A longitudinal investigation. Unpublished master's thesis, Middle East Technical University, Ankara.

Barnes, V., Potter, E. H., \& Fiedler, F. E.(1983). Effect of interpersonal stress on the prediction of academic performance. Journal of Applied Psychology, 68(4), 686- 697.

Black, S. (1990). Factors related to the adjustment of Japanese expatriate managers in America. Research in Personnel and Human Resources Management, 2, 109-125. 


\section{Psychological Well-Being in Student of Gender Difference}

Carmel S, Nigavekar A (2007) Gender differences among old persons Worldwide: Facts and Conclusions. Retrieved from http:/haecclientspublic.s3.amazonaws.com/ilcga/pdf/2010/12/10/Gender_Differences_among_Old_Perso ns_Worldwide_-_Facts_and_Conclusions.pdf

Chang, E. C. (2006). Perfectionism and dimensions of psychological well-being in a college student sample: A test of a stress-mediation model. Journal of Social \& Clinical Psychology, 25(9), 1001-1022.

Connors, J.V. (1990). Gender difference in perceived advancement problems, stress and satisfaction of university. Unpublished doctoral thesis, University of Missouri.

Cooke, R., Beewick, B. M., Barkham, M., Bradley, M., \&Audin, K. (2006). Measuring, monitoring and managing the psychological wellbeing of first year university students. British Journal of Guidance \&Counselling, 34(4), 505-517.

Crose, R., Nicholas, D. R., Gobble, D. C. \& Frank, B. (1992). Gender and wellness: A multidimensional system model for counseling. Journal of Counseling\& Development, 71,149-156.

Eagly, A.H (1987). Sex differences in social behaviour: A social-role interpretation. Hillsdale, New Jersey: LEA Publishers.

Erikson, E. H. (1959). Late adolescence. In D. H. Funkenstein (Ed.), The student and mental health. Cambridge, MA: Riverside Press.

Fernandes, H. M., Vasconcelos-Raposo, J., \& Teixeira, C. M. (2010). Preliminary analysis of thepsychometric properties of Ryff's scales of psychological wellbeing in Portuguese adolescents. The Spanish Journal of Psychology, 13(2), 1032-1043.

Gençöz, T. \&Özlale, Y. (2004). Direct and indirect effects of social support on psychologicalwell-being. Social Behavior and Personality, 32 (5), 449-458.

Inglehart, R. (2002): Gender, aging, and subjective well-being. International Journal ofComparative Sociology, 43: 391-408.

Jin, S. U., \& Moon, S. M. (2006). A study of well-being and school satisfaction among academically talented students attending a science high school in Korea. Gifted Child Quarterly, 50, 169-184.

Kasser, T., \& Ryan, R. M. (1993). A dark side of the American dream: Correlates of financial success as a central life aspiration. Journal of Personality and SocialPsychology, 65, 410422.

Kasser, T., \& Ryan, R. M. (1996). Further examining the American dream: Well -being correlates of intrinsic and extrinsic goals. Personality and Social PsychologyBulletin, 22, 281-288.

Kasser, T., \& Ryan, R. M. (2001). Be careful what you wish for: Optimal functioning and the relative attainment of intrinsic and extrinsic goals. In P. Schmuck \& K. Sheldon (Eds.),Life goals and wellbeing: Towards a positive psychology of human striving (pp. 116-131). Seattle, WA: Hogrefe.

Keyes, C. L. M., Shmotkin, D., \&Ryff, C. D. (2002). Optimizing well-being: The empirical 


\section{Psychological Well-Being in Student of Gender Difference}

encounter of two traditions. Journal of Personality and Social Psychology, 82, 10071022.

Kitamura, T., Matsuoka, T., Miura, S., \&Yamaba, K. (2004).Ryff's psychological wellbeing inventory: Factorial structure and life history correlates among Japanese university students. Psychological Reports, 94, 83-103.

Lu,L. (2000). Gender and conjugal differences in happiness (Electronic Version). Journal of Social Psychology. 140(1),

Maslow, A. (1968). Toward a psychology of being. (2nd ed.). New York, NY: Van NostrandReinhold.

McCann, S. J .H.,\&Meen, K. S. (1984). Anxiety, ability, and academic achievement.The Journal of Social Psychology, 124, 257-258.

Milem, J. F., Chang, M. J., \& Antonio, A. L. (2005). Making diversity work on campus: A research-based perspective. Washington, DC: Association of American Colleges and Universities.

Moon, S. M. (2003).Developing personal talent. In F. J. Mönks\& H. Wagner (Eds.), Development of human potential: Investment into our future. Proceedings of the8th Conference of the European Council for High Ability.(ECHA, pp. 11-21). Bad Honnef, Germany: K. H. Bock

Price, E., McLeod, P. J., Gleich, S. S., \& Hand, D.(2006). One year prevalence rates of major depressive disorder in first year university students. Canadian Journal ofCounselling, 40(2), 68-81.

Rogers, C. (1961). On becoming a person: A therapist's view of psychotherapy. Boston, MA:Houghton Mifflin.

Ryff, C. D. (1989a). Happiness is everything, or is it? Explorations on the meaning of psychological well-being. Journal of Personality and Social Psychology, 57(6), 10691081.

Ryff, C. D., \& Essex, M. J. (1992). The interpretation of life experience and well -being: The sample case of relocation. Psychology and Aging, 7, 507-51.

Ryff, C. D., \& Keyes, C. L. M. (1995). The structure of psychological well-being revisited. Journal of Personality and Social Psychology, 69(4), 719-727.

Ryff, C.D. \&Singer,B. (1998). The Contours of positive human health. Psychological Inquiry,9(1), 1-28

Schmutte, P. S., \&Ryff, C. D. (1997). Personality and well-being: What is the connection? Journal of Personality and Social Psychology, 73, 549-559. doi:10.1037/00223514.73.3.549.

Sheldon, K. M. (2005). Positive value change during college: Normative trends and individual differences. Journal of Research in Personality, 39(2), 209-223.

Strumpfer, D. J. W (1995). The Origins of health and strength: from 'salutogenesis' to 'fortigenesis'.South African Journal of Psychology.25 ,81-89.

Turner, L. H. \&Sterk, H. M. (1994).Differences that make a difference. Westport, Connecticut:Bergin \& Garvey publishers. 
Van Dierendonck, D. V. (2003). The construct validity of Ryff s scales of psychological wellbeing and its extension with spiritual well-being. Personality and Individual Differences, 36, 629-643. doi:10.1016/S0191-8869(03)00122-3.

Wintre, M. G., \&Yaffe, M. (2000). First-year students' adjustment to university life as a function of relationships with parents. Journal of Adolescent Research, 5(1), 9-37.

Wong, J. G., Cheung, E. P., Chan K. K., Ma, K. M., \& Tang, S. W. (2006). Web based survey of depression, anxiety and stress in first year tertiary education students in Hong Kong. Australian \& New Zealand Journal of Psychiatry, 40, 777782. 